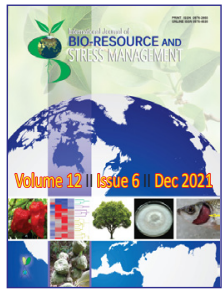

\title{
Effect of Nutrient Management and Rice Establishment Methods on Groundnut (Arachis hypogaea L.) in Rice-Groundnut Cropping System
}

\author{
T. K. Samant ${ }^{1 *}$, L. M. Garnayak' ${ }^{1}$, R. K. Paikaray ${ }^{1}$, K. N. Mishra ${ }^{2}$, R. K. Panda ${ }^{3}$ and S. K. Swain ${ }^{4}$
}

${ }^{1}$ Dept. of Agronomy, ${ }^{2}$ Dept. of Soil Sciences and Agril. Chemistry, ${ }^{3}$ Dept. of Plant Physiology, ${ }^{4}$ Directorate of Research, Odisha University of Agriculture and Technology, Bhubaneswar, Odisha (751 003), India

\begin{abstract}
Open Access
Corresponding Author

T. K. Samant

e-mail: tksamant_2003@yahoo.co.in

Citation: Samant et al., 2021. Soil Nutrient Analysis Underneath Grewia optiva Population. International Journal of Bio-resource and Stress Management 2021, 12(6), 663-669. HTTPS://DOI. ORG/10.23910/1.2021.2625.

Copyright: (c) 2021 Samant et al. This is an open access article that permits unrestricted use, distribution and reproduction in any medium after the author(s) and source are credited.

Data Availability Statement: Legal restrictions are imposed on the public sharing of raw data. However, authors have full right to transfer or share the data in raw form upon request subject to either meeting the conditions of the original consents and the original research study. Further, access of data needs to meet whether the user complies with the ethical and legal obligations as data controllers to allow for secondary use of the data outside of the original study.

Conflict of interests: The authors have declared that
\end{abstract} no conflict of interest exists.

\begin{abstract}
The field experiments were conducted at Agronomy Main Research Farm, Odisha University of Agriculture and Technology, Bhubaneswar, Odisha, India during rabi (November-March) seasons of 2019-2020 and 2020-2021 to evaluate direct and residual effect of nutrient management and rice establishment methods on phenology, growing degree days, growth, yield and economics of groundnut in rice-groundnut cropping system. The experiments were laid out in split-plot design with three replications. Carryover effect of direct seeding rice favourably influenced the succeeding groundnut crop as compared to that grown after transplanting which had superior growth parameters resulting in $25.7 \%$ higher pod yield, oil yield $\left(1.24 \mathrm{t} \mathrm{ha}^{-1}\right)$, gross return (₹ $136612.7 \mathrm{ha}^{-1}$ ) and net return ( $₹ 63965.0 \mathrm{ha}^{-1}$ ). Residual effect of organic management to preceding rice significantly increased growth, yield attributes, growing degree days at physiological maturity and net return, resulted in highest pod yield of $2.48 \mathrm{t} \mathrm{ha}^{-1}$ in groundnut which was at par with that grown after INM in rice, but was on an average, $17.0 \%$ higher than inorganic practice in rice. INM to groundnut increased yield parameters and economics of the crop resulting in 19.7 and $39.3 \%$ higher pod yields than $100 \%$ and $75 \%$ soil test based fertiliser, respectively. Hence, INM under direct seeding to kharif rice benefits the succeeding groundnut crop and direct application of $75 \%$ STBN (inorganic) $+25 \%$ STBN (FYM)+0.2 LR+biofertilisers to groundnut proved beneficial for improving phenology, growing degree days, growth, yield and economics of groundnut in rice-groundnut cropping system.
\end{abstract}

Keywords: Groundnut, phenology, yield, economics, rice-groundnut system

\section{Introduction}

Rice based cropping systems are of prime importance in global food production. Groundnut (Arachis hypogaea L.) considered as a unique and important legume oil seed crop grown over an area of 28.5 mha with a total production of $46 \mathrm{mt}$ in the whole world. In India groundnut is grown over an area of 4.9 mha with total production of $6.73 \mathrm{mt}$ (Anonymous, 2021). Continuous rice mono cropping and excessive dependence on chemical fertilisers degrade the soil quality, which can be partly solved by changing into rice-legume cropping system and inclusion of oilseeds and legumes in the cropping system has closer relationship between system productivity, energy and environment (Deep et al., 2018). Ricegroundnut is an important cropping system in Odisha. Both the crops in the system are nutrient exhaustive and sensitive to changing climate.

Article History

RECEIVED on $19^{\text {th }}$ September 2021 RECEIVED in revised form on $25^{\text {th }}$ November 2021 ACCEPTED in final form on $26^{\text {th }}$ December 2021 
Deterioration of soil properties due to improper crop and nutrient management has threatened the productivity and sustainability of the system in the state (Patra et al., 2019).

Organic manures and biofertilizers have carry-over effect on the succeeding crops in rice based cropping systems. Low productivity in groundnut is mainly due to low consumption of fertilizer in spite of prominent nutrient deficiencies and application of manures and fertilizers affects the availability of soil nutrients and soil physical properties of groundnut (Patil et al., 2017 and Mondal et al., 2019). Integrated Nutrient Management (INM) strategy will play significant role in plant nutrition for better crop production (Kamble et al., 2018; Annadurai et al., 2009) and is flexible and minimizes the use of chemicals and improve the soil health (Jana et al., 2020). Application of vermicompost with inorganic fertilizers is effective for improving the soil health and increases yields (Ravikumar et al., 2019 and Ghosh et al., 2021). Method of stand establishment influences the performance of rice crop and has great impact on field preparation and establishment of succeeding rabi crop. Transplantingin rice is detrimental to the succeeding non-rice crop due to deterioration of soil physical condition and formation of hard pan at shallow depth through puddling (Bandyopadhyay et al., 2019).

The information on residual effects of rice establishment methods and direct and residual effects of nutrient management practices on groundnut in rice-groundnut system is meagre. Growing degree days(GDD) and photo thermal units (PTU) are good estimators of crop growth stages (Prabhakar et al., 2007). The optimum diurnal air temperature for vegetative growth of groundnut is between 30 and $35^{\circ} \mathrm{C}$, whereas, for reproductive growth and final yield is some between 25 and $28^{\circ} \mathrm{C}$. High day temperature above $35^{\circ} \mathrm{C}$ during the reproductive phase reduce dry matter production, proportion of flowers from pegs, number of pods per plant, harvest index and pod yield (Prasad et al., 2001).

Severe drought stress at the vegetative stage and mild drought stress applied at the flowering stage in rice result in $20 \%$ and $28 \%$ yield loss, respectively (Yang et al., 2019). Variable environmental conditions can greatly influence stand establishment, crop development and yield in groundnut. Low temperature in the early season can also have pronounced effects on the physiology of seedlings, resulting in reduced plant growth and development (Virk et al., 2019). Plant growth ceases when temperature exceeds or drops below a critical minimum. The rise in temperature causes early maturity in crop. Climatic resources and their interactions with agricultural parameters help to increase the crop productivity (Ko et al., 2010). Keeping these above points in view, the present investigation was undertaken to find out direct and residual effect of nutrient management and rice establishment methods on phenology, growing degree days, growth, yield and economics of groundnut in rice-groundnut cropping system.

\section{Materials and Methods}

The field experiments for groundnut were conducted for two consecutive years during rabi (November-March) seasons of 2019-2020 and 2020-2021 at Agronomy Main Research Farm, Odisha University of Agriculture and Technology, Bhubaneswar (20¹5' N, 85 52' E, 25.9 m above MSL), Odisha, India. The soil of the experimental site was acidic in reaction $(\mathrm{pH}-5.28)$, loamy sand texture with medium organic carbon $(0.57 \%)$, phosphorus (15.4 kg ha ${ }^{-1}$ ) and potassium $(189.4 \mathrm{~kg}$ $\left.\mathrm{ha}^{-1}\right)$ and low in nitrogen ( $\left.187.5 \mathrm{~kg} \mathrm{ha}^{-1}\right)$ content. Six treatment combinations comprising of two establishment methods [direct seeded rice (DSR) and transplanted puddled rice (TPR)] and three nutrient management practices [inorganic- $100 \%$ soil test based fertilizers (STBF), organic- green manuring $+1 / 3^{\text {rd }}$ STBN (vermicompost) $+1 / 3^{\text {rd }}$ STBN (neem oil cake) and integrated nutrient management (INM)- green manuring+ $50 \% \mathrm{STBN}+100 \% \mathrm{P}_{2} \mathrm{O}_{5}+100 \% \mathrm{~K}_{2} \mathrm{O}$ ] to rice during kharif were allotted to the main-plots. Three nutrient management practices viz.,75\% STBF (inorganic), 100\% STBF (inorganic) and INM [75\% STBN (inorganic)+25\% STBN (FYM)+lime 0.2 LR+biofertilisers (Rhizobium and PSB)+100\% $\mathrm{P}_{2} \mathrm{O}_{5} 100 \% \mathrm{~K}_{2} \mathrm{O}$ ] to groundnut during rabi were allotted to the sub-plots in a split-plot design replicated three times at the same site during both the years in rice-groundnut cropping system. Rice ( $c v$. Maudamani-CR DHAN 307) and groundnut variety (cv. DeviICGV 91114) were grown on both the year. The seeds were dibbled and maintained one seed at the spacing of $25 \mathrm{~cm}$ x $10 \mathrm{~cm}$ at seed rate $125 \mathrm{~kg}$ kernel ha ${ }^{-1}$ at a depth of $5 \mathrm{~cm}$. Soil test based nitrogen, phosphorous and potassium were applied at the rate of 25 : 40: $40 \mathrm{~kg} \mathrm{~N}, \mathrm{P}_{2} \mathrm{O}_{5}$ and $\mathrm{K}_{2} \mathrm{O}$ ha $^{-1}$ in the form of urea, di-ammonium phosphate and muriate of potash respectively. The matured groundnut plants were uprooted from the net plot area of each plot separately. The pods were separated from the plants, the soil particles adhering to the mature pods were removed and developed pods were completely dried under the sun for five days. All the growth, yield attributes and yield of both crops were recorded as per standard procedures.Growing degree days (GDD) was calculated by using Peterson equation (1965).

\section{Growing degree days $=\left(T_{\max }+T_{\min }\right) / 2-T_{\text {base }}$}

Where, Tmax and Tmin are the daily maximum and minimum temperature $\left({ }^{\circ} \mathrm{C}\right)$, and $\mathrm{T}_{\text {base }}$ is the base temperature $\left(10^{\circ} \mathrm{C}\right)$

Available soil nutrient contents were determined following the standard procedures (Jackson, 1973). The data collected from the experiment on various observations were subjected to pooled analysis as prescribed by Gomez and Gomez (1984).

\section{Results and Discussion}

\subsection{Phenology}

Nutrient management and rice establishment methods in rice influenced the phenology of succeeding groundnut (Table 1). The numbers of days for attaining various phonological stages in succeeding groundnut differed with different nutrient 
Table 1: Duration and growing degree days of different phonological stages of groundnut in rice-groundnut cropping system under nutrient management and rice establishment methods

\begin{tabular}{|c|c|c|c|c|c|c|c|c|c|c|}
\hline \multirow{2}{*}{$\begin{array}{l}\text { Treat- } \\
\text { ment }\end{array}$} & \multicolumn{5}{|c|}{ Duration (days) } & \multicolumn{5}{|c|}{ Growing degree days $\left({ }^{\circ} \mathrm{C}\right.$ day $\left.^{-1}\right)$} \\
\hline & $\begin{array}{l}\text { Flower } \\
\text { initiation }\end{array}$ & $\begin{array}{l}\text { Peg for- } \\
\text { mation }\end{array}$ & $\begin{array}{c}\text { Pod } \\
\text { initia- } \\
\text { tion }\end{array}$ & $\begin{array}{c}\text { Seed } \\
\text { initia- } \\
\text { tion }\end{array}$ & $\begin{array}{c}\text { Physiological } \\
\text { maturity }\end{array}$ & $\begin{array}{c}\text { Flower } \\
\text { initia- } \\
\text { tion }\end{array}$ & $\begin{array}{l}\text { Peg for- } \\
\text { mation }\end{array}$ & $\begin{array}{c}\text { Pod } \\
\text { initia- } \\
\text { tion }\end{array}$ & $\begin{array}{c}\text { Seed } \\
\text { initia- } \\
\text { tion }\end{array}$ & $\begin{array}{l}\text { Physiologi- } \\
\text { cal maturity }\end{array}$ \\
\hline \multicolumn{11}{|c|}{ Rice establishment method } \\
\hline DSR & 30.5 & 45.8 & 50.2 & 64.7 & 120.6 & 450.8 & 660.1 & 707.2 & 851.4 & 1617.8 \\
\hline TPR & 31.7 & 46.6 & 51.1 & 65.6 & 122.7 & 411.7 & 566.9 & 623.0 & 818.5 & 1749.2 \\
\hline SEm \pm & 0.14 & 0.03 & 0.05 & 0.06 & - & 2.5 & 0.8 & 0.8 & 1.1 & 0.7 \\
\hline $\begin{array}{l}C D \\
(p=0.05)\end{array}$ & 0.44 & 0.09 & 0.13 & 0.17 & - & 7.9 & 2.4 & 2.4 & 3.5 & 2.1 \\
\hline \multicolumn{11}{|c|}{ Nutrient management in rice } \\
\hline Inorganic & 31.5 & 46.7 & 51.2 & 65.7 & 121.7 & 440.5 & 621.0 & 671.7 & 842.4 & 1658.8 \\
\hline Organic & 30.7 & 45.7 & 50.2 & 64.7 & 121.8 & 423.8 & 607.7 & 659.6 & 828.8 & 1711.6 \\
\hline INM & 31.0 & 46.0 & 50.5 & 65.0 & 121.5 & 429.6 & 611.9 & 663.9 & 833.7 & 1680.0 \\
\hline SEm \pm & 0.17 & 0.04 & 0.05 & 0.07 & - & 3.1 & 1.0 & 0.9 & 1.4 & 0.8 \\
\hline $\begin{array}{l}C D \\
(p=0.05)\end{array}$ & 0.53 & 0.12 & 0.16 & 0.21 & - & 9.7 & 3.0 & 2.9 & 4.3 & 2.6 \\
\hline \multicolumn{11}{|c|}{ Nutrient management in groundnut } \\
\hline $\begin{array}{l}75 \% \\
\text { STBF }\end{array}$ & 31.3 & 46.4 & 50.9 & 65.4 & 122.3 & 435.4 & 616.7 & 667.9 & 838.1 & 1695.1 \\
\hline $\begin{array}{l}100 \% \\
\text { STBF }\end{array}$ & 31.1 & 46.2 & 50.7 & 65.2 & 121.4 & 431.7 & 613.7 & 665.6 & 835.5 & 1665.6 \\
\hline INM & 30.8 & 45.9 & 50.3 & 64.8 & 121.5 & 426.7 & 610.0 & 661.8 & 831.2 & 1689.8 \\
\hline SEm \pm & 0.04 & 0.04 & 0.05 & 0.07 & - & 0.8 & 0.6 & 0.6 & 0.7 & 0.6 \\
\hline $\begin{array}{l}C D \\
(p=0.05)\end{array}$ & 0.12 & 0.11 & 0.15 & 0.20 & - & 2.4 & 1.7 & 1.7 & 2.1 & 1.9 \\
\hline
\end{tabular}

management and rice establishment methods. Residual effect of transplanting in rice (TPR) resulted higher crop duration in succeeding groundnut than direct seeding (DSR) and showed higher requirement of days for attaining various phonological stages like flower initiation, peg formation, pod initiation, seed initiation and harvest maturity as compared to DSR. Residual effect of organic management showed the minimum requirement of days to complete various phonological stages of succeeding groundnut up to physiological maturity as compared to INM and inorganic. The results also indicated that residual effect of INM resulted minimum requirement of days of 121.5 followed by organic and inorganic (121.7 and 121.8 respectively). As regards to direct application of treatment to groundnut, integrated use of organic and inorganic sources of nutrients (INM) to groundnut recorded minimum requirement of days to complete various phonological stages followed by organic and inorganic except physiological maturity. This might be due to genetic potentiality of crop and variety which can response well to the prevailed weather conditions during crop growth enabling to escape possible high temperature stress at later growth stages and efficient utilization of available growing degree days to complete each phonological stages (Kingra and Kaur, 2013; Singh, 2003). Samant and Swain (2020) also reported the similar types of results in rice.

\subsection{Growing degree days (GDD)}

Effect of nutrient management and establishment methods of rice on heat unit of growing degree days (GDD) was significant at all the phonological stages of succeeding groundnut (Table 1). The lowest heat unit (GDD) requirement was observed in flower initiation and increased in the successive phonological stages peg formation, pod initiation, seed initiation and harvest maturity. Residual effect of DSR showed significantly higher GDD than TPR in all growth stages except harvest maturity which indicated that transplanting stress delayed crop development on the order of $1749.2^{\circ} \mathrm{C}$ day mean thermal units. Similarly, carry over effect of organic management in 
rice required minimum GDD at all the phonological stages of succeeding groundnut followed by INM and inorganic except physiological maturity. Organic recorded the maximum GDD requirement for maturity $\left(1711.6^{\circ} \mathrm{C}\right.$ day $\left.^{-1}\right)$, followed by INM and inorganic (with a mean of 1680.0 and $1658.8^{\circ} \mathrm{C}$ day $^{-1}$ respectively) at physiological maturity owing to higher life span and efficient utilization of heat as compared to inorganic and INM. Similar findings were reported by Islam and Sikder (2011) in rice under organic and inorganic conditions.

Direct application of $75 \%$ STBF to groundnut resulted in the maximum GDD of $1695.1^{\circ} \mathrm{C}$ followed by $100 \%$ STBF and INM might be due to difference in prevailing daily mean temperature in a particular year (Kumar et al., 2020).

\subsection{Growth and yield attributes}

Carryover effect of DSR favourably influenced the growth and yield attributes in succeeding groundnut crop as compared to that grown after TPR. The leaf area index, seeds pod $^{-1}$ and 100 pod weight was not affected due to rice establishment (Table 2). DSR produced significantly higher plant height (39.5 $\mathrm{cm}$ ), dry matter accumulation (27.9 g plant $^{-1}$ ), nodules plant ${ }^{-1}$ (83.5) and pods plant ${ }^{-1}$ (18.0) and shelling percent (72.5). Besides early maturity, DSR also offers the option to resolve edaphic conflicts between rice and the subsequent non-rice crop and enhance sustainability of the rice-based cropping system and succeeding winter crops (Farooq et al., 2011, Yadav et al., 2018).

Table 2: Growth and yield attributes of groundnut in rice-groundnut system under nutrient management and rice establishment methods

\begin{tabular}{|c|c|c|c|c|c|c|c|c|}
\hline Treatment & $\begin{array}{l}\text { Plant } \\
\text { height } \\
(\mathrm{cm})\end{array}$ & $\begin{array}{c}\text { Leaf area } \\
\text { index }\end{array}$ & $\begin{array}{l}\text { Dry matter } \\
\text { accumulation } \\
\left(\text { g plant }^{-1}\right)\end{array}$ & $\begin{array}{l}\text { Nodules } \\
\text { plant }^{-1}\end{array}$ & $\begin{array}{l}\text { Pods } \\
\text { plant }^{-1}\end{array}$ & $\begin{array}{l}\text { Seeds } \\
\text { pod }^{-1}\end{array}$ & $\begin{array}{c}100 \text { pod } \\
\text { weight (g) }\end{array}$ & $\begin{array}{c}\text { Shelling } \\
(\%)\end{array}$ \\
\hline \multicolumn{9}{|c|}{ Rice establishment method } \\
\hline DSR & 39.5 & 3.29 & 27.9 & 83.5 & 18.0 & 1.86 & 88.7 & 72.5 \\
\hline TPR & 36.6 & 3.13 & 25.2 & 81.1 & 16.0 & 1.65 & 88.4 & 71.3 \\
\hline SEm \pm & 0.3 & 0.12 & 0.5 & 0.9 & 0.12 & 0.10 & 0.8 & - \\
\hline $\operatorname{CD}(p=0.05)$ & 0.9 & NS & 1.5 & NS & 0.4 & NS & NS & - \\
\hline \multicolumn{9}{|c|}{ Nutrient management in rice } \\
\hline Inorganic & 34.7 & 2.98 & 24.4 & 78.0 & 16.1 & 1.58 & 84.8 & 71.3 \\
\hline Organic & 41.5 & 3.36 & 28.7 & 86.8 & 18.2 & 1.94 & 91.6 & 72.4 \\
\hline INM & 38.0 & 3.29 & 26.6 & 82.1 & 16.6 & 1.73 & 89.2 & 72.1 \\
\hline SEm \pm & 0.4 & 0.15 & 0.6 & 1.1 & 0.15 & 0.13 & 0.9 & - \\
\hline $\operatorname{CD}(p=0.05)$ & 1.1 & NS & 1.8 & 3.5 & 0.4 & 0.37 & 2.7 & - \\
\hline \multicolumn{9}{|c|}{ Nutrient management in groundnut } \\
\hline $75 \%$ STBF & 31.6 & 3.03 & 24.9 & 76.6 & 16.1 & 1.58 & 84.6 & 70.9 \\
\hline $100 \%$ STBF & 42.9 & 3.16 & 26.9 & 78.0 & 16.7 & 1.74 & 89.3 & 71.8 \\
\hline INM & 39.6 & 3.44 & 27.9 & 92.3 & 18.2 & 1.94 & 91.7 & 73.1 \\
\hline SEm \pm & 0.3 & 0.24 & 0.8 & 1.6 & 0.29 & 0.23 & 0.4 & - \\
\hline $\mathrm{CD}(p=0.05)$ & 0.8 & NS & NS & 4.6 & 0.8 & 0.64 & 1.2 & - \\
\hline
\end{tabular}

Residual effect of nutrient management in rice also exerted significant influence on growth and yield attributes of succeeding groundnut crop. Significantly higher plant height $(41.5 \mathrm{~cm})$, dry matter accumulation (28.7 g plant $\left.^{-1}\right)$, nodules plant $^{-1}(86.8)$, pods plant ${ }^{-1}(18.2)$, seeds pod ${ }^{-1}$ (1.94), 100 pod weight (91.6 g) and shelling percent (72.4) were recorded under the residual effect of organic management in the respective years followed by INM and the lowest was with inorganic practice, but no significant effect was noticeable in LAI (Gowthami and Ananda, 2017) .

As regards to direct application of treatment to groundnut, no significance effect was observed in LAl and dry matter accumulation though their numerical values under integrated use of organic and inorganic sources of nutrients were 3.44 and 27.9 g plant $^{-1}$ respectively. Significantly higher nodules plant $^{-1}$, pods plant ${ }^{-1}$, seeds pod ${ }^{-1}, 100$ pod weight and shelling percent were observed in INM whereas plant height was observed in $100 \%$ STBF (Baishya et al., 2014). Similar findings had been recorded in greengram by Mohanty et al. (2014).

\subsection{Yield}

The nutrient management and rice establishment method had significant influence on pod yield, haulm yield and harvest index of subsequent groundnut (Table 3 ). 
Table 3: Yield and economics of groundnut in rice-groundnut cropping system under nutrient management and rice establishment methods

\begin{tabular}{|c|c|c|c|c|c|c|c|}
\hline Treatment & $\begin{array}{c}\text { Oil yield } \\
\left(\mathrm{t} \mathrm{ha}^{-1}\right)\end{array}$ & $\begin{array}{c}\text { Pod yield } \\
\left(\mathrm{t} \mathrm{ha}^{-1}\right)\end{array}$ & $\begin{array}{c}\text { Haulm yield } \\
\qquad\left(\mathrm{t} \mathrm{ha}^{-1}\right)\end{array}$ & $\begin{array}{c}\text { Harvest } \\
\text { index (\%) }\end{array}$ & $\begin{array}{l}\text { Gross return } \\
\left(₹ \mathrm{ha}^{-1}\right)\end{array}$ & $\begin{array}{l}\text { Net return } \\
\left(₹ \mathrm{ha}^{-1}\right)\end{array}$ & $\begin{array}{l}\mathrm{B}: \mathrm{C} \\
\text { ratio }\end{array}$ \\
\hline \multicolumn{8}{|c|}{ Rice establishment method } \\
\hline DSR & 1.24 & 2.59 & 3.59 & 41.7 & 136612.7 & 63965.0 & 1.66 \\
\hline TPR & 0.98 & 2.06 & 3.49 & 36.9 & 108528.2 & 36925.3 & 1.54 \\
\hline SEm \pm & 0.02 & 0.034 & 0.053 & 0.71 & - & - & - \\
\hline $\operatorname{CD}(p=0.05)$ & 0.07 & 0.1 & 0.16 & 2.2 & - & - & - \\
\hline \multicolumn{8}{|c|}{ Nutrient management in rice } \\
\hline Inorganic & 1.00 & 2.12 & 3.31 & 38.4 & 111580.9 & 39730.4 & 1.86 \\
\hline Organic & 1.18 & 2.48 & 3.65 & 40.2 & 130937.2 & 58558.0 & 1.06 \\
\hline INM & 1.13 & 2.37 & 3.66 & 39.2 & 125193.3 & 53047.1 & 1.88 \\
\hline SEm \pm & 0.03 & 0.042 & 0.065 & 0.82 & - & - & - \\
\hline $\operatorname{CD}(p=0.05)$ & 0.09 & 0.12 & 0.19 & 2.7 & - & - & - \\
\hline \multicolumn{8}{|c|}{ Nutrient management in groundnut } \\
\hline $75 \%$ STBF & 0.92 & 1.96 & 3.43 & 36.3 & 103375.3 & 39115.8 & 1.57 \\
\hline $100 \% S T B F$ & 1.08 & 2.28 & 3.57 & 38.8 & 120167.4 & 48161.4 & 1.60 \\
\hline INM & 1.31 & 2.73 & 3.62 & 42.8 & 144168.7 & 64058.3 & 1.64 \\
\hline SEm \pm & 0.05 & 0.07 & 0.108 & 1.30 & - & - & - \\
\hline $\mathrm{CD}(p=0.05)$ & 0.14 & 0.2 & 0.31 & 3.7 & - & - & - \\
\hline
\end{tabular}

1 US \$=INR 74.53; 72.80 during average of March month of 2020 and 2021

Carryover effect of DSR favourably influenced the succeeding groundnut crop as compared to that grown after TPR resulting in higher oil yield (1.24 t ha-1) and $25.7 \%$ higher pod yield (Table 3 ). The haulm yield and harvest index also showed the similar trends. This might be due to deterioration of soil physical condition and formation of hard pan at shallow depth through puddling in TPR which was detrimental to the succeeding non-rice crop (Bandyopadhyay et al., 2019).

Residual effect of organic nutrient management to preceding rice crop in the respective years resulted in the highest oil yield (1.18 $\mathrm{t} \mathrm{ha}^{-1}$ ) and pod yield of $2.48 \mathrm{t} \mathrm{ha}^{-1}$. This was on a par with that grown after INM practice in rice, but was on an average, $17.0 \%$ higher than that grown after inorganic practice in rice owing to availability of continuous and balanced supply of nutrients for a prolonged period due to residual effect of organic to preceding rice which confirm the findings of Prasad et al. (2002).

Integrated use of organic and inorganic sources of nutrients (INM) to groundnut resulting in 19.7 and 39.3\% higher pod yield over 100 and 75\% STBF, respectively. This might be owing to increased solubility and availability of $\mathrm{N}$ in the rhizosphere due to biofertilisers, improvement of soil $\mathrm{pH}$ due to lime and physico-chemical properties due to FYM, and instant availability of nutrients from inorganic fertilisers (Ibrahim et al., 2017; Singh et al., 2013).

\subsection{Economics}

The study on economics (Table 3 ) revealed that DSR fetched higher net returns ( $₹ 136612.7 \mathrm{ha}^{-1}$ ) as compared to TPR. Similarly, The net return value under DSR, on an average, was ₹ 27039.7 ha $^{-1}$ more than TPR. DSR also improved the $\mathrm{B}: \mathrm{C}$ to 1.66 as compared to TPR during due to relatively less cost of cultivation in conformity with Bohra and Kumar (2015). Organic management to rice resulted in the higher gross returns, net returns and $\mathrm{B}: \mathrm{C}$ over INM and inorganic nutrition might be due to higher yield under organic practice. INM to groundnut recorded net returns ( $₹ 64058.3 \mathrm{ha}^{-1}$ ) and B:C (1.64) with increasing the corresponding values by $₹ 24942.5 \mathrm{ha}^{-1}$ and 0.07 unit over $75 \%$ STBF and $₹ 15896.9$ ha $^{-1}$ and 0.04 unit over $100 \%$ STBF. This was due to higher system yield under INM, which might have negated the relatively higher cost of organic sources of nutrients in line with the findings of Samant (2015) and Chaudhay et al. (2015).

\section{Conclusion}

Thus, integrated nutrient management practice in conjunction with dhaincha green manuring $+50 \%$ STBN $+100 \% \mathrm{P}_{2} \mathrm{O}_{5}$ $+100 \% \mathrm{~K}_{2} \mathrm{O}$ under direct seeding to kharif rice benefits the succeeding groundnut crop in rice-groundnut system. Direct application of $75 \%$ STBN (inorganic) $+25 \%$ STBN (FYM) +0.2 $\mathrm{LR}+$ biofertilisers (Rhizobium and PSB) to groundnut crop is the 
recommended nutrient management practice for improving phenology, growing degree days, growth, yield and economics of groundnut in rice-groundnut cropping system.

\section{References}

Annadurai, K., Puppala, N., Angadi, S., Masilamani, P., 2009. Agronomic management technologies for peanut production: A review. Agricultural Review 30(4), 235-261.

Anonymous, 2021. Statista Research Department, Sept 15, 2021, https://www.statista.com/statistics/769471/ india-groundnut-production.

Baishya, L.K., Ansari, M.A., Singh, R., Deka, B.C., Prakash, N., Ngachan, S.V., 2014. Response of groundnut (Arachis hypogaea L.) cultivars to integrated nutrient management on productivity, profitability and nutrient uptake in $\mathrm{NEH}$ region, Indian Journal of Agricultural Sciences 84(5), 612-615.

Bandyopadhyay, K.K., Sarangi, A., Kumar, R.D., Singh, D.K., 2019. Effect of puddling and direct sowing of rice on soil physical health and water productivity of rice-wheat cropping system under different irrigation regimes. Journal of Indian Society of Soil Sciences 67(2), 160-173.

Bohra, J.S., Kumar, R., 2015. Effect of crop establishment methods on productivity, profitability and energetics of rice (Oryza sativa)-wheat (Triticum aestivum) system. Indian Journal of Agricultural Sciences 85(2), 217-223.

Chaudhary, J.H., Sutaliya, R., Desai, L.J., 2015. Growth, yield, yield attributes and economics of summer groundnut (Arachis hypogaea L.) as influenced by integrated nutrient management. Journal of Applied and Natural Science 7(1), 369-372.

Deep, M., Kumar, R.M., Saha, S., 2018. Rice-based cropping systems for enhancing productivity of food grains in India: decadal experience of AICRP. Indian Farming 68(01), 27-30.

Farooq, M., Siddique, K.H.M., Rehman, H., Aziz, T., Lee, D.J., Wahid, A., 2011. Rice direct seeding: experiences, challenges and opportunities. Soil and Tillage Research 111, 87-98.

Ghosh,M., Ashiq,W., Bhogilal Vasava, H., Gamage,D.N.V., Patra, P.K., Biswas, A., 2021. Short-term carbon sequestration and changes of soil organic carbon pools in rice under integrated nutrient management in India. Agriculture 11, 348.

Gomez, K.A., Gomez, A.A., 1984. Statistical procedures for agricultural research. A Willey Inter Science Publication, New York, 76-83.

Gowthami, V.S., Ananda, N., 2017. Dry matter production, yield and yield components of groundnut (Arachis hypogaea L.) genotypes as influenced by zinc and iron through ferti-fortification. Indian Journal of Agricultural Research 51(4), 339-344.

Ibrahim, M.M., Yusuf, A.A., Daudu, C.K., 2017. Optimizing biological nitrogen fixation and yield of groundnut (Arachis hypogaea L.) in an acidic alfisolthrough rhizobium inoculation, liming and fertilization Nigerian. Journal of Scientific Research 16(2), 190-196.

Islam, M.R., Sikder, S., 2011. Phenology and degree days of rice cultivars under organic culture. Bangladesh Journal of Botany 40(2), 149-153.

Jackson, M.L., 1973. Soil chemical analysis. Prentice Hall of India Private Limited, New Delhi.

Jana, K., Mondal, R., Mallick, G.K., 2020. Growth, productivity and nutrient uptake of aerobic rice (Oryza sativa L.) as influenced by different nutrient management practices. Oryza 57(1), 49-56.

Kamble, B.M., Kathmale, D.K., Rathod, S.D., 2018. Soil nutrient status, uptake, yield and economics of groundnut-wheat cropping sequence as influenced by organic sources and fertilizers. Journal of the Indian Society of Soil Science 66, 66-75.

Kingra, P.K., Kaur, P., 2013.Phenology and growth dynamics of groundnut (Arachis hypogaea L.) cultivars under different dates of sowing. Journal of Research Punjab Agricultural University 50(1 \& 2), 24-31.

Ko, J., Ahujab, L., Kimballc, B., Anapallib, S., Mab, L., Greenb, T.R., Ruaned, A.C., Wallc, G.W., Pinterc, P., Badere, D.A., 2010. Simulation of free air $\mathrm{CO}_{2}$ enriched wheat growth and interactions with water, nitrogen, and temperature. Agricultural and Forest Meteorology 150, 1331-1346.

Kumar, P., Singh, K., Sharma, K.D., Kumar, A., Kumar, A., 2020. Direct and residual effect of planting method and phosphorous levels on productivity and agrometeorological indices, thermal and energy efficiencies in mungbean-wheat cropping system. Legume Research 43(1), 111-116.

Mohanty, T.R., Roul, P.K., Maity, S.K., Nayak, A., 2014. Productivity and profitability of greengram (Vigna radiate L.) as influenced by rice crop establishment and nutrient management practices in rice-greengram cropping system. Journal of Crop and Weed 11(1), 92-97.

Mondal, R., Goswami, S., Mandi, S.K., Goswami, S.B., 2019. Quality seed production of rice (Oryza sativa L.) as influenced by nutrient management during kharif season in the lower Indo-Gangetic plains. Environment and Ecology 37(1A), 274-280.

Patil, D.B., Pawar, P.P., Wadile, S.C., Patil, H.M., 2017. Effect of integrated nutrient management on growth and yield of kharif groundnut (Arachis hypogaea L.). International Journal of Horticulture, Agriculture and Food science 1(1), 21-23.

Patra, A.K., Garnayak, L.M., Mishra, K.N., Mohanty, T.R., Mohapatra, B.K., Swain, S.K., 2019. Balanced fertilization in rice (Oryza sativa)-groundnut (Arachis hypogaea) cropping system. Indian Journal of Agronomy 64(3), 293-297. 
Peterson, R.F., 1965. Wheat crop series, Ed. Polunin, N., Inter Science Publication Inc. New York, P, 422.

Prabhakar, B.N., Halepyati, A.S., Desai, B.K., Pujari, B.T., 2007. Growing degree days and photo thermal units accumulation of wheat (Triticum aestivum L. and $T$. durum Desf.) genotypes as influenced by dates of sowing. Karnataka Journal of Agricultural Sciences 20(3), 594-595.

Prasad, P.V.V., Craufurd, P.Q., Kakani, V.G., Wheeler, T.R., Boote, K.J., 2001. Influence of temperature during pre and post-anthesis stages of floral development on fruit-set and pollen germination in groundnut (Arachis hypogaea L.). Australian Journal of Plant Physiology 28, 233-240.

Prasad, P.V.V., Satyanarayana, V., Murthy, V.R.K.,Boote, K.J., 2002. Maximising yields in rice-groundnut cropping sequence through integrated nutrient management. Field Crops Research 75(1), 9-21.

Ravikumar, C., Ganapathy, M., Ganesamoorthy, D., Kartikeyan, A., Saravanaperumal, M., Murugan, G., 2019. Effect of INM on growth, yield and quality parameters of irrigated groundnut (Arachis hypoagea L.) var. VRI-2 for sandy loam soils. Plant Archives 19(2), 745-749.

Samant, T.K., 2015. System productivity, profitability, sustainability and soil health as influenced by rice based cropping systems under mid-central table land zone of Odisha. International Journal of Agriculture Sciences 7(11), 746-749.
Samant, T.K., Swain, S.K., 2020. On-farm assessment of medium duration Rice (Oryza sativa L.) cultivars for growth, yield, economics and stress tolerance. International Journal of Bio-resource and Stress Management 11(4), 398-404.

Singh, A.L, 2003. Phenology of groundnut. Advances in Plant Physiology 6, 295-382.

Singh, G.P., Singh, P.L., Panwar, A.S., 2013. Seed yield quality and nutrient uptake of groundnut (Arachis hypogaea) as affected by integrated nutrient management in mid hill attitude of Meghalaya, India. Legume Research 36(2), 147-152.

Virk, G., Pilon, C., Snider, J.L., 2019. Impact of first true leaf photosynthetic efficiency on peanut plant growth under different early-season temperature conditions. Peanut Sciences 46(2), 162-173.

Yadav, N., Yadav, S.S., Yadav, N., Yadav, M.R., Kumar, R., Yadav, L.R., Yadav, L.C., Sharma, O.P., 2018. Growth and productivity of groundnut (Arachis hypogaea L.) under varying levels and sources of sulphur in semiarid conditions of Rajasthan. Legume Research 41(2), 293-298.

Yang, X., Wang, B., Chen, L., 2019. The different influences of drought stress at the flowering stage on rice physiological traits, grain yield, and quality. Scientific Reports 9, 3742. 